\title{
Concurrent Narratives of Māori and Integration in the 1950s and 60s
}

AROHA HARRIS, TE RARAWA, NGĀPUHI

In Te Atatu in the early 1960s, a group of young Māori mothers and their children enjoyed three Māori sessions a week at their local play centre. They called themselves the Waipareira Play Centre. Meanwhile in Henderson, another West Auckland suburb, the Jacobs family sometimes held Catholic services in Māori in their home. The Te Atatu women and the Jacobs had essentially created Māori enclaves in their predominantly Pākehā neighbourhoods. And they had achieved that against the grain, at a time when integrating Mãori into New Zealand's social and economic mainstream was the main goal of Māori policy. Not only was integration the goal but, from 1961, implementation of J.K. Hunn's Report on Maori Affairs made it a goal to be pursued as a matter of urgency, for the good of Māori and all New Zealanders, and in the spirit of harmonious race relations.' Yet these Mãori West Auckland innovations waxed and did not wane in a period usually characterised as one of social and cultural decline for Māori.

The theme of decline in the post-war period may be attributed, at least in part, to the potency of the state's narratives in the telling of histories about Māori. However, Māori narratives, too, can play an important role in the telling and understanding of Māori experiences of the 1950s and $60 \mathrm{~s}$. The innovations exemplified by the Waipareira Play Centre and the Jacobs family represent small steps towards larger goals - goals that stood outside the policy frame of integration and inside the frame of Māori creative energy. Several of the parents behind the play centre, particularly Letty Brown, were also instrumental in setting up a tribal committee, the Te Atatu branch of the Mãori Women's Welfare League and, later, Hoani Waititi Marae. Similarly, Pio and Chrissy Jacobs were key contributors to the voluntary efforts behind Te Unga Waka, the marae and Māori Catholic church that opened in Epsom, Auckland, in 1966. These developments were seeded and nurtured on the challenging, often adverse and - importantly - tribally spoken-for cityscapes of the post-war Māori world. Yet they were, in effect, transplanted from, and historically rooted in, more familiar and forgiving rural tribal homelands.

This article considers Māori and government policies of integration in the $1950 \mathrm{~s}$ and $60 \mathrm{~s} .{ }^{2}$ It shapes the telling of that history by accessing two 
concurrent narratives: the narratives of the state embedded in a one-sizefits-all Māori policy, and the narratives of the Māori 'business of life'. The state's narratives have long dominated histories about Māori, and New Zealand historians and researchers are familiar with its archives, its official publications and media coverage of its work. So, historiographically speaking, the state's narratives are well watched. The Māori narratives are more likely situated among the great un-watched. They reside primarily, though not exclusively, among the oral life histories of Māori people themselves, and historians and researchers have varying degrees of exposure to, and experience with, them. Each set of narratives has its problems, which are further complicated by the location from which this history is viewed and written, that is, the academic and authorial location on the uneven, shaky and often contested ground between Māori and western scholarships. The key obstacles to be navigated may be summarised (and clearly over-simplified) under an overarching tension between subjectivity and objectivity: western scholarship often questions subjectivity; Māori scholarship embraces and even demands it. Both scholarships have methods for dealing with subjectivity. However each scholarship, perhaps, differently appreciates and treats the subjectivity of its sources and scholars.

Māori scholars are often at work on projects with their own hapū and iwi, largely because their hapũ and iwi demand it, and also because of the indivisibility of their academic and hapū selves. Thus Māori scholars are well-placed to attract accusations of bias. In their work, some Māori historians write Māori up from under the oppressive weight of New Zealand's grand narratives. ${ }^{4}$ Others intellectually repatriate to their tribal homelands, to return to and reinvigorate the indigenous historical trajectory that pre-dates colonisation. More and more, then, Māori historians are involved in writing histories that aim to escape the past into which Māori have been written, that is, the dominant historical discourse through which the Mãori past has been watched, and within which Māori history tends to be understood as little more than a subject of British colonialism and expansionism. ${ }^{5}$ Overall, they aim to do what Linda Smith urges: to 'reprioritize and reconcile what is important about the past with what is important about the future'. 6

Some careful navigation of the tensions that arise is required. Māori scholarship values, and can emphasise, oral sources - the spoken accounts of life, of experience and of reality. It can and does use documentary evidence, including the state's, but it does so critically, maybe even suspiciously, aware that the so-called official record is the record of the coloniser, of the legislator and governor who observed and wrote. Māori scholarship has also generated its own documents, some in relationship to the state and some indifferent to it, with access governed entirely by Māori protocols. Māori scholarship has protocols that allow research participants an influential say 
about the projects to which they contribute. This often means that whānau - or, at least, participants in the research - can and will continue to have a say about it, even though the whannau may easily be viewed as biased and constraining. Yet those whānau influences also constitute complete relationships that encompass obligation and responsibility and privilege. It may be argued that Maaori scholars work well in such situations not simply because they are Māori, but because of their relationship with both the past that they study and its actors. An example may be taken from my own access to the Mangamuka Māori Association (later, Tribal Committee) Minute Books. It was facilitated in the first instance by whakapapa, which gave me eligibility and a basis from which I could know the books existed and ask to study them. Though the books were held by my grandmother Violet Otene Harris, that eligibility was no guarantee of access. This had to be worked out and worked for within a long nana-mokopuna-researcherresearched dynamic that probably began in my childhood when I first asked Nana for help with a school project.

Much about the tensions between western and indigenous scholarships is becoming more well-known, though not always better negotiated. Māori historians, writers and researchers understand the methods, standards and demands of western scholarship, and understand there are both tensions and degrees of compatibility. That difficult terrain between scholarships is a challenging place from which to listen to the lives of the Māori people, who are both the objects - in policy terms - of Māori Affairs and one of the main narrators of its history. Hazardous but navigable, it is nonetheless a location that facilitates access to Māori narratives and allows those narratives to shape history and not merely accessorise it. It is a location that not only gives voice to Māori history, but encourages that voice to register - to sing the lead and not be restricted to the role of brown back-up singer. It is a location from which the future of Māori history, the Māori future of the past, looks brighter than it might otherwise. Within the history of Māori and Māori Affairs, within the processes of researching and writing, are some examples of navigating the tensions presented by working concurrently with official and Māori narratives. They are, hopefully, examples that step towards reconciliation rather than a non-engaging treatment that might view such tensions as mutually exclusive; examples that counter-balance each other, rather than simply counter. Hopefully, also, the navigation of these tensions is achieved without forsaking the tools, either Māori or western, of the historians.

One example of concurrent narratives may be seen in the interactions between Māori creative energies and government policies of integration in the 1950s and 60s. The Mãori and state narratives screen each other out as well as intersect, often in an unsynchronised way. In the business of daily 
life, Māori selected their interactions with the state, generally on the basis of local-level or whannau need. On the other hand, the Department of Māori Affairs consistently interpreted and measured Māori against the success or failure of their integration into mainstream society. The narratives are inseparable yet discordant. They are the narratives of people who arrived in the post-war era by way of separate historical trajectories. The tensions to be navigated are therefore convoluted and multi-layered, and further complicated by the underlying engagements between Māori and western scholarships.

The goals of amalgamation, assimilation and integration successively framed New Zealand governments' policies toward Māori which aimed - in midto late-twentieth century terms - to integrate Māori into New Zealand's mainstream. In the post-war period, expressions of integration as a policy goal were initially ad hoc, though the Department of Māori Affairs was clearly the policy's main carrier. Referred to in Māori idiom as 'the Māori Affairs', the department was, for Māori, the most important agent of the state, and it is difficult to appreciate its pervasiveness in post-war Māori lives. In the 1950s, integration was applied on the ground via a complex and congested nexus through which the team of Māori welfare officers who staffed the department's Welfare Division worked closely with a communitybased leadership organised into tribal committees and branches of the Mãori Women's Welfare League. It was an old approach made new: the idea was that the leadership and energies of iwi Māori, appropriately organised and guided, could be influenced to support a government policy, equally as old, of 'whitening' Māori.? According to the department's under-secretary, Tipi Ropiha, the 1945 Maori Social and Economic Advancement Act was entirely about the 'full integration of the Mâori race into the social and economic structure of the country'. Under Ropiha's leadership, which lasted through to 1957, the Welfare Division's work emphasised 'social education' and aimed to encourage a level of Māori community control and direction 'in the essentials of good citizenship and civic responsibility'. Amongst their many duties and responsibilities, tribal committees were required to balance the acceptance and maintenance of 'the full rights, privileges, and responsibilities of citizenship' with the preservation and revival of 'Maori arts, crafts, language, genealogy, and history in order to perpetuate Maori culture'. ${ }^{8}$ In effect, they had to steer Māori along the path to modernity without neglecting their cultural needs. It was a difficult job, inadequately resourced. Despite the nod of approval to Māori culture in general, there was nothing to indicate how or if tribal committees would be supported in the task of preserving and maintaining its components. Still, relationships between Māori communities and Māori Affairs were workable, if variable; 
they were continually negotiated and consistently underscored by a measure of Māori cynicism and suspicion about the state.

The enduring vision of integration was one in which Māori moved, not only from tribal homeland to town, but from an historical position of cultural difference and outsiderhood to one of difference within a shared national ethos. ${ }^{9}$ When there was a change of government from National to Labour in 1957, the Secretary of Māori Affairs, Mortimer Sullivan, reiterated Ropiha's earlier words that the 'full integration' of Mãori was a key goal. Sullivan noted a number of modern-day challenges facing Māori, including delinquency and heavy drinking, which were 'symptoms of a deeper social disorder'. But he also indicated that integration had to account for Māori desires to retain Māori ways of doing and being. The department, he wrote, did not expect all community structures to be abandoned:

A large number of Maori people still find the old community structure intensely meaningful and beneficial and while working for those people's individual material advancement, we must respond to their frequently expressed aspirations for a good and progressive community life with balanced material, social and cultural features."

Arguably, it was Jack Hunn who first attempted an official written expression of what the department meant by integration, and he took great care to relegate assimilation to the dustbin of a less-enlightened past. Hunn asserted that assimilation meant 'to become absorbed, blended, amalgamated with complete loss of Maori culture'. Integration, on the other hand, would see Māori and Pākehā elements combine in a natural process to form a single nation that allowed Māori culture to remain distinct." On the face of it, Hunn's rendition of integration was no different than other explanations variously articulated since the 1945 Act; Hunn simply clarified the position that, indeed, integration was the intent of Mãori policy. But he went further, calling for, and later implementing, a harder and faster approach. He illustrated his position by classifying Māori into three groups. Group A was comprised of assimilated Māori, a 'completely detribalised minority' retaining mere traces of Māoritanga; group $B$ comprised the integrated majority of Māori comfortable in both Māori and Pākehā societies and able to participate in both; and group $\mathrm{C}$ consisted of the unassimilated and unintegrated, 'another minority complacently living a backward life in primitive conditions'. Hunn advocated that Māori policy should aim to eliminate the complacent and backward minority group $\mathrm{C}$ and raise it up to join the comfortable majority in group B. Progressing to the detribalised group A was a matter of personal choice available to the successfully integrated B group..$^{12}$ Even if Māori had deigned to agree with Hunn's three groups, they might have represented them differently. It was arguably group 
$\mathrm{C}$ and its 'backward' life-ways that gave group B the cultural wherewithal to maintain its Māoriness. Group A would also likely seek out group C when questing, in later decades, to reconnect to its Māoritanga. In many respects, Hunn's group $\mathrm{C}$ was one of few constants in a society undergoing phenomenal change.

Hunn defined integration as a natural and inevitable process, and also assumed it to be progressive, permanent and irreversible. Rather than favouring some unnatural process, Hunn said all he proposed was that government could and should hasten the pace of integration as a matter of policy. An example of integration in action may be seen in the programme begun in 1955 to mainstream Māori schools by transferring their control to the Education Boards. By 1961, however, only six out of more than 100 schools had transferred. This low number may be attributed to the principle of not forcing the transfers, instead allowing them to occur on request or when the time was 'opportune'. ${ }^{3}$ Following Hunn's recommendations, a firm date was set: all Mãori schools would be closed by the beginning of the 1969 school year. The rationale for stepping up the programme was that urbanisation - integration's accomplice, and similarly natural and inevitable - would lead to more Mãori children attending board schools in urban areas, and an improvement in the quality of Mãori education would result. However, the National Committee on Māori Education warned that a change in administration and in name did not absolve the boards from addressing Māori needs, most importantly the need to ensure Māori children learned 'Maoritanga'.'4 Many Māori shared this view, including the Māori Women's Welfare League and the New Zealand Māori Council, who each made specific proposals for the inclusion of Māori language, arts, history and culture in the school curriculum. ${ }^{15}$ Unfortunately, their proposals struggled to find support. While the government agreed in principle that those who wanted to learn te reo Māori ought to be able to do so, it remained largely indifferent to the application of resources to the task. Maintaining te reo, which Hunn regarded as having a limited chance of success anyway, was a matter for the individual (and not the whannau, hapū or community).

In application, then, Hunn's integration compared unfavourably to the gentler, more community-focused approach of the 1950s. He urged Māori to 'turn to the ordinary agencies for their ordinary business', and the pattern of accelerating integration through a process of mainstreaming was repeated in other policy areas.$^{16}$ Hunn saw opportunities for integration everywhere. Miscegnation was 'inexorably integrating, even assimilating' Mãori and Pākehā. Schools were the 'nursery of integration'; housing a 'strong force for it'; employment a means of 'comingling the races in all ranks of society'; and the object of land title reform was to imitate European titles. The harder, faster approach to integration fractured the already delicate, 
though workable, relationships between Mãori and the Department of Māori Affairs. Hunn wanted welfare work to be "cut down to the bare essentials' and the Māori welfare officers removed from the time-wasting 'exhortatory work on the marae'. ${ }^{17}$ Mãori welfare work was increasingly bureaucratised. Its focus shifted from cultivating the nexus between Māori and the Māori Affairs to case work with individuals and families, and the welfare officers were encouraged to call more often on the expertise of "professional social workers' employed in other departments. ${ }^{18}$

Hunn did insist there was some room for cultural difference, but not much as it transpired, and rarely in public spaces. Cultural difference was consistently haunted by the spectre of racial discrimination - particularly in accommodation and employment. It was never resourced for survival and was largely targeted for elimination in the wake of the Hunn Report. ${ }^{19}$ The future of Māori culture and society, and the extent to which policy would support it, was a poorly articulated, murky area. Some broad natural limits were imposed by a governmental insistence that whatever the end result of integration, New Zealand could only ever comprise one people. Within that frame lay a set of unanswered questions about the nature and extent of the Māori world in modern, integrated form. Hunn's view that integration was a natural process extended to the survival of Mãori society - those elements worthiest of preservation would survive on their own merits. There was little if any discussion about what elements of Mãori society ought to survive, how they were to survive or who would determine them. Instead, there was a substantial grey area, where the things that were important to Māori - and yet somehow difficult to explain across the cultural divide that separated Māori and Pākehā -competed with the forces of integration for a secure position in modern New Zealand. It was in this grey area of adjustment that Māori worked out the creative tensions between tradition and modernity, policy and practice, theoretical Māori worlds and daily Māori lives.

Generally, according to the political rhetoric of the time, integration required Māori to shift - mind, body and soul - from the cultural comfort of their tribal homelands to modern, urban New Zealand, apparently the natural habitat of the good citizen. The good citizen was a product of the good family, and was well-behaved, law-abiding, healthy, educated, employed and economically independent. These are not particularly enlightening desires - surely most families share them. However, for Māori citizens, this kind of talk was code for integration; the Mãori citizenry could only exist in a mainstream (Pākehā) frame. So women of the Māori Women's Welfare League were told, on the eve of their inaugural conference, that good citizens were created in good homes where good mothers raised 'good and healthy 
children, who [would] be a credit to the race'.20 Good citizens owned their land individually and not communally as Māori did; and good citizens ensured all the land they did own was productive and therefore contributing to, and not burdening, the national economy.

Despite the apparent uniformity and conformity of good citizenship, the unlimited variables within and between individual Māori families gave rise to a countless number of possible outcomes and experiences as they transitioned from rural tribalism to modern, urban citizenship. However, their life histories share one major commonality: a place called 'home'. Typically a Māori community that pivoted around a marae, home could be geographically located: a hamlet on the shores of the Hokianga, a larger township on the East Coast, a remote settlement up a river or down a valley, a bay-side papakāinga encroached upon by a city built on its doorstep. Even people who had lived at the same urban address for more than forty years shared similar ideas about home. In effect, they had two homes: the one from which they originated; and the one they had created in a distant, but not entirely disconnected, place.

For Māori who urbanised in the 1950s and 60s, and to whom the attention of this article now turns, home was not necessarily constrained by its geography; it also held sophisticated and important ideological blueprints that structured society and culture. ${ }^{21}$ Home was a safe place, or, more accurately, a collection of safe places networked by blood relations among whom adults shared responsibilities for all children - theirs and others. Young children were unquestionably and unconditionally 'whāngai-ed' by grandparents or other relatives. ${ }^{22}$ Children ate and slept at different households within their home communities, knowing - as their parents knew - that they were among family. Young people attended dances and socials under the watchful eyes of aunts and uncles, who regulated dress and behaviour. ${ }^{23}$ Home-grown processes were instituted for disciplining and educating young people, which might include their being sent to live temporarily with relatives while attending school or in the aftermath of disputes in the home. ${ }^{24}$ Home was also a cooperative place. The spoils of hunting and fishing were distributed among the wider whannau, rather than kept only for the immediate families of the hunters and fishers. ${ }^{25}$ Communities fundraised to rebuild and maintain marae, and co-operated in their farming and gardening endeavours. ${ }^{26}$ Fundamentally, home was demographically Māori. The few Pākehā at home were likely the teachers, shopkeepers or policemen, and in some cases only the family head 'used to talk to Păkehās'. ${ }^{27}$ So, despite the lure of an independent life in the exciting city, the strong sense of Māori community and belonging - spun from whakapapa, knitted together, kept alive and viable by the shared attitudes and values of the group - could be difficult to leave. ${ }^{28}$ 
The strong pull of home is usefully illustrated by an example from Letty Brown's life history. For Letty, who was instrumental in the establishment of the Waipareira Play Centre, home was (and is) Te Araroa, at least geographically. Ideologically, home was the comfort and bosom of her whãnau. Letty first attended school at Tikitiki, staying there with an aunty because the family home at Te Araroa was too far from school. At the age of about seven, she returned to Te Araroa to finish primary school. After two years at Gisborne Intermediate, during which time she stayed with a grand-uncle, Letty attended St Joseph's Māori Girls' College, largely at the behest of Aunty Lena, for three years. Letty's final year of school was spent back at Te Araroa at Rerekohu Māori District High. Soon after finishing, Letty's whānau sent her off to Auckland to train as a teacher, a practical expression of their pride in her educational attainment. In fact, she did not go directly to teachers' training college, instead taking a job as a toll operator for the New Zealand Post Office. ${ }^{29}$

This simple chronicle of Letty's school years indicates that support for her education came from beyond the immediate family and moved her beyond the physical bounds of Te Araroa. Furthermore, Letty recalled that her education was important not only to her parents but to the whole community. The adult women Letty knew as a child were 'strong Ngāti Porou women', and they expected educational achievement from all their children, girls and boys. Letty's experience does not mean to say that all young Māori in the post-war period were similarly encouraged to pursue a modern education, although undoubtedly many were. The key point is that home communities (Hunn's group $\mathrm{C}$ ) offered guidance and support for getting on in the modern world (group B). In Letty's example, she grew up knowing she 'had to be educated' and recalled feeling 'fortunate that good influences' surrounded the young people of Te Araroa. ${ }^{30}$ Those influences came into play again at a later time, after marriage and amidst raising her family of five children, when Letty trained as a play centre supervisor. Her central role in establishing the Waipareira Play Centre essentially evolved from her perception that Māori children in her neighbourhood missed out on preschool education largely because their mothers were uncomfortable when outnumbered, and therefore socially and culturally swamped, by Pākehā. When Letty diplomatically inquired amongst Mãori mothers in her community about their apparent disinterest in the local play centre, the most common responses were about being 'too shy' or 'whakamā'. These references were occasionally expressed as negative stereotypes of Pākehã; some women commented that there were 'too many Pākehās' or that they 'can't stand Pākehās'. For Letty, these comments were timely reminders of the alien Păkehã nature of play centre, and they were equally matched by the 'shock' expressed by most parents and staff at the Te Atatu Play 
Centre when she innocently suggested the establishment of a weekly Māori session. After three meetings, much discussion and debate, and some public criticism, the session was established. The great achievement, in Letty's view, was creating something that was 'just like being back home'. Māori parents rallied around the Waipareira Play Centre, started a 'culture group' and started fundraising with the goal of covering the cost of their children's fees. ${ }^{31}$ That small act alone - of generating a communal approach to paying fees normally paid by individual families - was probably enough to qualify as a departure from the official prescription for integration.

Chrissy and Pio Jacobs' approach to urbanisation was similarly organic and creative, and stressed the role of the church compared to Letty's emphasis on education. From the late 1950s, the couple established their West Auckland home and family in a way that kept them in tune with the rendition of Mãori Catholicism that over generations had harmonised with the social and cultural tribal life of North Hokianga. At the foundations of their family home was the value attached to maintaining existing connections for the benefit of their children - connections to people from home and to fellow Mãori Catholics. What this meant in practice was that, instead of attending the church near their home, the Jacobs preferred either to travel to the Catholic Centre in the city, where they knew other Hokianga Catholics congregated, or to arrange family-oriented Māori services in their home. ${ }^{32}$ That was their strategy for ensuring their continued participation in 'the miha Māori' (Māori mass). After the Catholic Centre closed, Pio and Chrissie joined the Auckland Māori Catholic Society - the group that established Te Unga Waka Marae. ${ }^{33}$ Pio then became known amongst Hokianga Catholics living in West Auckland as someone who could be relied upon for a ride to church at 'Waka' on Sundays. Later, both he and Chrissy participated in a number of non-sectarian voluntary and social groups that based themselves at Te Unga Waka, including a branch of the Māori Women's Welfare League. What had begun for them as a commitment to family evolved into wider roles within a particular section of the Māori community that was simultaneously laying down roots in the city while retaining tribal life-ways.

It could easily be argued that home was largely the nostalgic creation of a generation encouraged to relocate to the city. Indeed, such an argument may help to explain the apparent absence of stories of negative experiences of home, even though those stories and realities are known to exist. It would be a mistake, therefore, to romanticise home and homogenise its people. That said, people's awareness of home did heighten after they left it, as it was brought into sharp relief by the glow of 'the golden city'. ${ }^{34}$ Reflecting on home from the distant city meant it could be both romanticised and vilified. Home had the best kai and was a comfortable, relaxed, even healing place to be, where no one suffered the discomfort of having to explain 
themselves across the cultural divide. But the folks back home could also be unsophisticated and, to the chagrin of welfare officers, unenterprising. At home, there was nothing for young people to do. In the city, there was plenty of paid work for everyone who wanted it, and a dance with live music could be found practically every night of the week. ${ }^{35}$ But the city also had its pitfalls. City living could result in the dreaded detribalisation for some, especially for young people who moved beyond the reach of the social sanctions of their elders. And petty racism was an everyday occurrence. Still, threaded through these various understandings and experiences was reference to a kind of leadership that gave children in the cities social and cultural ground rules. Whannau participation and support, and the guidance of elders, feature throughout the Māori narratives. Influential leaders were local and familiar, like the father who wanted his daughters to be educated, the aunties at the dance who wanted all the young people to be nicely dressed and the uncle who encouraged church attendance. In offering rudimentary guidelines for a good life, parents, grand-parents, aunts and uncles also provided a framework for social interaction.

In effect, then, escaping the kāinga did not necessarily mean escape from the whannau. Relatives eased the transition from school to work, country to city, Te Araroa to Auckland, Te Hauhanga to Whangarei. Relatives made big moves less lonely. They took new migrants to dances, helped them to find work, had them join the same rugby and netball teams and carpooled for visits home. Caroline Reeves was assisted into her first city job by an aunt, and also enjoyed the support of family members when she caught tuberculosis. ${ }^{36}$ Tom Parore moved from Te Hauhanga near Dargaville to Whangarei and integrated with his relatives in cricket and rugby teams. ${ }^{37}$ The integrating experiences of Margaret Harris - a North Hokianga Catholic, like the Jacobs - follow a similar pattern. Though Margaret admits that at times her church attendance 'lapsed', she persistently regarded the Catholic Church as an important part of family life, and the mix of Catholicism and familial relationships eased her transition to Auckland ${ }^{38}$ Her first job was as a kitchen hand at Sacred Heart College in Glen Innes, where her older sister also worked, and where she was taken under the wing of 'Aunty Olive Rapira'. Aunty Olive was 'sort of a house mother' to all the girls who worked at the college. Margaret remembered that Aunty Olive was 'always dressed nicely' and that she encouraged the girls to keep themselves clean and tidy, enforced the domestic tikanga the girls would have grown up with, such as not combing their hair in the kitchen, and made sure everyone went to church on Sundays ${ }^{39}$ For Margaret, Catholicism and church attendance were not just a demonstration of faith or doctrinal allegiance, but were also integral to her social and cultural world. 
Cultural reconnection in the cityscape could easily include all sorts of extra-tribal or extra-denominational connections. Indeed, as Pio Jacobs pointed out, being at work from Monday to Friday and joining in at sports, church and a variety of functions around the city on the weekends meant he could 'make many friends from other tribes all the way down to Taranaki' ${ }^{40}$ So, in the emerging modern Māori New Zealand, patterns of kin relationships also extended to non-kin situations. As a Māori mother and wife raising a family in West Auckland, Letty Brown said she placed a high premium on the relationships that young people had with aunts and uncles, the kinds of relationship she had experienced growing up in Te Araroa. She ensured her own children were surrounded by extra-tribal aunts and uncles, the urbanising Māori with whom Letty chose to network. It was years, according to Letty, before her children realised that the numerous aunties and uncles they grew up with were not all, in fact, kin. ${ }^{41}$ What developed, in the meantime, was that the language of family and whānau was applied to a non-family, or new family, environment. Sports teams, community centres, churches and workplaces soon became sites for these new families. Margaret Harris socialised with other non-kin, urbandwelling Māori by joining sports teams. She variously played housewives' netball, basketball, softball, badminton and tennis with 'all the Māori ladies around' the neighbourhood. The women shared childcare responsibilities and transport to facilitate their participation. ${ }^{42}$

In the cities, gathering together around sports, church or dances could restore - even if only temporarily - the comfort and familiarity of home. Caroline Reeves practised her Ratana faith in Auckland at a time when the church had no fixed location. Sometimes services were held at the Mãori Community Centre, sometimes at a hired Masonic Hall. When she was 'at home' Caroline said she went to church because 'it was compulsory'. In Auckland, however, when she was working and on her own, she found she 'wanted to go to church'. Her distance from home evoked the example of her grandfather, a Ratana āpōtoro (apostle, minister), and a sense that being Ratana was part of being herself. ${ }^{43}$ Thus, whether she had planned it that way or not, home followed Caroline to town.

In the cities, strangers with similarities became friends and whannau with whom difference could be shared, and the groups that formed around the basic tenet of shared difference often used the things they missed about home as a template for tribalising in the city. Māori people's similarities were carried not only in the language or elusive definitions of Māoritanga, but also in the mundane: the taking off of shoes at the door, or the shared enjoyment of kaimoana and distinctly Māori foods. Kai Māori holds a prominent place in the life histories drawn on here. The Māori Community Centre in central Auckland could be relied upon for a good Māori feed after 
church on Sundays. Margaret Harris said she knew where to find toheroa at some of Auckland's west coast beaches, though they 'weren't the same as getting them from home'. Letty Brown said she 'hungered for the kai we missed' and often visited an aunt in Grey Lynn for 'a good boil up' and news from home. ${ }^{44}$ So food - kai Māori specifically, or kai from home - had the power to do more than satiate an appetite. It was often accompanied by (Māori) social or inter- and intra-whānau exchanges. Māori looked the same as each other, understood each other in ways that required no explanation, and ate the same foods, some of which could be sneered at in certain company. They somehow put down roots in the cities, while simultaneously retaining tribal life-ways that transcended tribal boundaries.

Home also played its part by, for example, provisioning its people with kai from home, taking temporary care of young children to relieve working parents and maintaining marae. Margaret spoke of home as a place to take the family for long weekends and holidays, funerals and birthdays, as well as a vital source of kaimoana. After such visits, she and her family often returned to Auckland with a stock of kumara and other vegetables, milk and cream, home-killed beef or pork, fish, kütai and toheroa - depending on seasonal availability. Sometimes the food would be redistributed amongst family members in Auckland. Margaret's mother- and father-in-law, Violet and Karanga Harris, supplied their children with these important provisions of home long after they had left and marked out their adult lives in the city. ${ }^{45}$

Food, however, was but one contribution from home. According to his widow, Karanga Harris applied the principle of supporting those who moved away from home to his engagement with Māori Affairs' title improvement policies. When the department repeatedly urged Karanga to seek sole title to the family block he farmed, by receiving the interests of his sisters who had all moved away, Karanga firmly declined. The land was from their mother and he wanted it 'to remain the same'. He argued that it was because 'everybody had gone' that they ought to maintain their interests, and besides, the land was 'mo ngā mokopuna' (for the grandchildren). Karanga did not explicitly reject the department's requests; he simply built his view on a different ethos, with the goal of maintaining the cultural integrity and intent of his family. Those principles could also extend beyond family and into the wider hapũ community. In opposition to Hunn's suggestion that it should be compelled to spend more on education, the Te Aupouri Māori Trust Board made clear its decision to prioritise the upkeep and development of its marae. ${ }^{46}$ It was an acknowledgement that the important role of the hunga kainga, to whom responsibility for the marae fell, was expanded rather than diminished by the advent of a population of newly urbanised Mãori. A decreasing rural population had to maintain whole marae complexes (which 
generally included churches, cemeteries and other community facilities) not just for their own use, but also for the use of those who lived in the cities and continued to call on the resources of the marae for family events such as birthdays, weddings, tangihanga and hura kōhatu. The role of the hunga kāinga as guardian of tradition and source of soul food - both literal and figurative - was one undertaken even though home was under great pressure, targeted for elimination by integration, and subsisting on conditional land development programmes.

Discerning some of the key components of home - kin, kai and karakia - may be straightforward enough. More complicated, and perhaps more important, is the malleability of home and its ideological hold. Home not only tugged at the heart strings, it also pulled some of the modern extratribal community development strings, effectively providing a template for integration on Māori terms. So, many Māori who moved to the cities in the 1950 s and $60 \mathrm{~s}$ - whether they knew it or not - effectively participated in marking out (non-tangata whenua) extra-tribal Māori socio-cultural spaces within an urban landscape dominated by Pākehā. In doing so, they drew on the social and cultural storehouses of home: the things Māori missed the most about home became the things they most wanted to provide for their children as they grew up. Hence Letty's leadership in establishing the Waipareira Play Centre led naturally, in later years, to her active support for the establishment of Hoani Waititi Marae; and the Jacobs' pursuit of the miha Māori to their involvements at Te Unga Waka. To some degree, urban environments enter into this history not because urbanisation somehow happened to Mãori, but because understandings of home were so often filtered through and integral to urbanisation experiences, and because home did not stop influencing people just because they had moved away from it. Yet the state's rendition of integration with its emphasis on urbanisation posed a direct threat to home; complete depopulation seemed imminent and home in a perpetual state of decline. However, population alone did not account for its viability. There always have been people at home, however few, all of them whanaunga, and all of them responsible for a role that expanded rather than contracted as their people moved away.

The state's goals of integration were overlaid onto this richly textured, nuanced and sophisticated world in which individual daily lives collectivised around shared aspirations for continuing the imperatives of the tribe, while facing - and often struggling with - the challenges that modern New Zealand presented. It is from this world that Māori narratives may be accessed to help tell a Māori history of Māori policy, one that includes accounts of the tenacity and strength of the cultural pull of home, and its influence on Māori people's engagements with the processes of modernisation. This is something 
for which policy-makers like Hunn did not, and probably could not, account. Certainly home cannot be discerned in the files of the Department of Māori Affairs. Rather, notions of home, and even the word itself, arose directly and uncompromisingly from the oral histories. Similarly, Māori and state narratives differently appreciate the creative energies expended in Māori engagement with the processes of urbanisation. The Māori narratives provide important understandings of Māori-state relations unavailable in the reams of information preserved in government archives. They allow consideration of a history that occurs in the gaps between policy and people, in the tensions between continuity and change, and in the engagements between Mãori and western scholarships. Not all the tensions and obstacles that could be addressed have been addressed, nor are they in any way resolved (and perhaps resolution is an ineffective goal). But working through and with them perhaps gives the Māori past a rosier future than one in which Māori narratives fail to reach beyond a secondary role of culturally adorning those of the state. Māori narratives, at the very least, are worth not only watching but also writing. To let them remain as 'great un-watched' narratives would be an unfortunate and unimaginative historical disservice.

1 J.K. Hunn, Report on Department of Maori Affairs (1960) with Statistical Supplement, Wellington, 1961 (Hunn Report). Ostensibly an account of Māori assets and how they might be applied for the benefit of Māori, the report was commissioned by Walter Nash's Labour Government in 1960, but was not published until 1961 under the incoming National Government's Minister of Māori Affairs. Ralph Hanan.

2 This article is based on a paper given at The Future of the Past: Sovereignty and Dominion, People and Places', New Zealand Historical Association Conference, Victoria University of Wellington, 23-25 November 2007.

3 Hirini Kaa asserts that the 'business of life' is the only 'determinant of autonomy' available to those who study their iwi in the twentieth century. as the nineteenth century's armed conflict and "legislative pillage' of Maori land fades. Hirini Kaa, "Te Wiwi Năti": The Cultural Economy of Ngati Porou, 1926-1939', MA thesis, University of Auckland, 2000 , p. 112.

4 Such as Ranginui Walker, Ka Whawhai Tonu Matou, rev. edn, Auckland, 2004.

5 The nature of Maori history is variously discussed and debated in: Danny Keenan, 'Predicting the Past: Some Directions in Recent Maori Historiography', Te Pouhere Korero, 1, 1 (1999), pp.25-35 and 'Ma Pango Ma Whero Ka Oti: Unities and Fragments in Maori History', in Bronwyn Dalley and Bronwyn Labrum, eds, Fragments: New Zealand Social Policy and Cultural History, Auckland, 2000, pp.39-53; Joseph Pere, 'Hitori Maori', in C. Davis and P. Lineham, eds, The Future of the Past: Themes in New Zealand History, Palmerston North, 1991; Monty Soutar, 'A Framework for Analysing Written Iwi Histories', He Pukenga Korero, Koanga, 2, 1 (1996), pp.43-57; Te Maire Tau, 'Matauranga Maori as Epistemology', Te Pouhere Korero, 1, 1 (1999), pp.10-23; Charles Royal, Te Haurapa: An Introduction to Researching Tribal Histories and Traditions, Wellington, 1992; and Maori Marsden, 'God, Man and Universe: A Maori View', in Michael King, ed., Te Ao Hurihuri: The World Moves On, rev. edn., New Zealand, 1975, pp.143-63. 
6 Linda Tuhiwai Smith, Decolonizing Methodologies: Research and Indigenous Peoples, London and Dunedin, 1999, p.39.

7 The notion of whitening Māori is borrowed from James Belich's 'racial lenses', through which whites viewed Māori as inherently salvageable, capable of learning and then living the white man's way. See James Belich, 'Myth, Race and Identity in New Zealand', New Zealand Journal of History (NZJH), 31, I (1997), pp.9-22, and Making Peoples: A History of the New Zealanders from Polynesian Settlement to the End of the Nineteenth Century, Auckland, 1996, pp.19-22.

8 Under-secretary (later Secretary) to Minister of Māori Affairs, 14 December 1949, MA 1, W2459, 1/1/41 pt 1, Archives New Zealand, Wellington (ANZW).

9 For example, see the addresses of the Minster of Māori Affairs and the Prime Minister to the inaugural conference of the Māori Women's Welfare League (MWWL), Minutes of the Inaugural Conference of MWWL, Wellington, 25- 27 September 1951, MA 1, 36/26/18 part 1, ANZW.

10 Secretary to Minster of Māori Affairs, 16 December 1957, AAMK 869/3a, 1/1 pt 1, ANZW.

11 Hunn Report, p.15.

12 Hunn Report, p.16.

13 Hunn Report, p.25. See also J. Barrington and T. Beaglehole, Maori Schools in a Changing Society, Wellington, 1974, pp.238-60.

14 Te Ao Hou, 62 (1968), pp.27, 43.

15 See, for example, Minutes of a meeting of the New Zealand Maori Council (NZMC), 28 \& 29 June 1962, MA 1, 35/2/1 pt 1, ANZW.

16 Hunn, Opening Speech to Inaugural Conference of the NZMC, MA 1, 35/2 vol 2, ANZW.

17 Hunn Report, pp.78-81.

18 See: Interim Advice No. 252, 12 January 1961, MA 1, 17/1/1 pt 1, ANZW; 'Comments on Balanced Development by Maori Affairs Department', 21 June 1961, MA 1, 19/1/131, ANZW; and additional details contained in AAMK 869/1101d and AAMK 869/1101e, ANZW.

19 By 1960 , both specific incidents of racial discrimination against Māori and broader issues of racial attitudes were well-recorded in Māori Affairs files and discussed in academic and public circles. See, for example: 'Non Legal Discrimination' memorandum and schedule, 1 April 1960, and various newspaper clippings, MA 1, 36/1/21 pt 2, ANZW; Report on Maori Housing Survey by the Waitemata District Council MWWL. 10 August 1952, MA 1, 30/lA pt I, ANZW; J. Harre, 'A Case of Racial Discrimination in New Zealand', Journal of the Polynesian Society, (JPS), 72, 2 (1962), pp.258-59; D. Ausubel. The Fern and the Tiki: an American View of New Zealand National Character. Social Attitudes and Race Relations, Sydney, 1960; and R. Thompson, 'Maori Affairs and the New Zealand Press Part I', JPS, 63, 4 (1953), pp.366-383 and 'Maori Affairs and the New Zealand Press', JPS, 64, 1, 1954, pp.1-16.

20 Notes for Minster of Maori Affairs visit to Hiruharama, 26 May 1951, MA 1, 1/1/47 pt 2, ANZW.

21 Aroha Harris. 'Dancing with the State: Maori Creative Energy and the Policies of Integration, 1945-67, PhD thesis, University of Auckland, 2007, pp.50-61. Everyone interviewed for the thesis talked about, and similarly conceptualised, their 'home'.

22 Caroline Reeves, interviewed by Aroha Harris, 8 September 1998, Tape 1 Side A.

23 See, for example, Letty Brown, interviewed by Aroha Harris, 25-27 May 1998, Tape I Side A; and Margaret Harris, interviewed by Aroha Harris, 28 May 1998, Tape I Side A. 


\section{Concurrent Narratives of Māori}

24 Pat Hohepa recorded a number of instances in Waima, Hokianga, in the late 1950s where disputes within households resulted in offenders leaving home, a feature that is supported by the oral evidence. See P. Hohepa, A Maori Community in Northland, Wellington, 1970, pp.84-93; and, for example, Taipari Munro, interviewed by Aroha Harris, 6 July 1998, Tape 1 Side B.

25 Brown interview, Tape I Side A; and Pio and Christina Jacobs, interviewed by Aroha Harris, 12 May 1998, Tape I Side B.

26 Mangamuka Marae Association and Mangamuka Tribal Committee Minute Book, private papers, V.O. Harris. Specific examples are discussed in: A. Harris, "Maori and "the Maori Affairs", in B. Dalley and M. Tennant, eds, Past Judgemem: Social Policy in New Zealand History, Dunedin, 2004, pp.195-96.

27 For example, Reeves interview, Tape 1 Side A.

28 Letty Brown, in particular, talked about reluctance to leave home. Brown interview, Tape 1 Side A.

29 For a fuller account of Letty Brown's transition from Te Araroa to Auckland see: Aroha Harris, 'Letty Brown, Wahine Toa', in Lyndon Fraser and Katie Pickles, eds, Shifting Centres: Women and Migration in New Zealand History, Dunedin, 2002, pp.103-116.

30 Brown interview, Tape I Side A.

31 Ibid.

32 Jacobs interview, Tape 1 Side B.

33 Brown interview, Tape I Side B.

34 'The golden city' is an image from Hone Tuwhare, 'The Old Place', in M. Orbell, ed., Contemporary Maori Writing, Wellington, 1970, p.51.

35 The frequency of dances and live music was mentioned as one of the main characteristics of the times in interviews with Caroline Reeves, Tom Parore, Margaret Harris and Letty Brown, for example.

36 Reeves interview, Tape 1 Side A.

37 Tom Parore, interviewed by Aroha Harris, 6 July 1998, Tape 1 Side A.

38 Margaret Harris interview, Tape 1 Side $A$.

39 Ibid., Tape I Sides A and B.

40 Ibid., Tape I Side A.

41 Brown interview, Tape 1 Side B.

42 M. Harris interview, Tape 1 Side A.

43 Reeves interview, Tape 1 Side A.

44 Brown interview, Tape 1 Side A.

45 Violet Otene Harris, interviewed by Aroha Harris, 2-3 July 1998, Tape 3 Side B. See also Mana, 69 (2006), pp.11-12.

46 George Walker to J.K. Hunn, 19 May 1961, AAMK 869/8b, 1/1/42 pt 2, ANZW. 